\title{
Heart involvement in Rheumatoid Arthritis: Systematic review and meta-analysis 2 , 岤岤
}

\author{
Salvatore Corrao a,b,*, Silvia Messina a , Giovanni Pistone ${ }^{\mathrm{b}}$, Luigi Calvo a \\ Rosario Scaglione ${ }^{a}$, Giuseppe Licata ${ }^{a}$ \\ a Centre of Research for Effectiveness and Appropriateness in Medicine (CREAM), Biomedical Department of Internal Medicine and Subspecialties [DiBiMIS], University of Palermo, \\ Palermo, Italy \\ ${ }^{\mathrm{b}}$ National Relevance Hospital Trust, Unit of Internal Medicine II, Outpatient Rheumatology Clinic, ARNAS Civico, Di Cristina e Benfratelli, Palermo, Italy
}

\section{A R T I C L E I N F O}

\section{Article history:}

Received 20 April 2012

Received in revised form 7 May 2012

Accepted 11 May 2012

Available online $\mathrm{xxxx}$

\section{Keywords:}

Rheumatoid Arthritis

Systematic review

Meta-analysis

Echocardiography assessment

Pericardial disease

Cardiac valvular calcification

\begin{abstract}
A B S T R A C T
Objective: The aim of our study was to conduct a systematic review with meta-analysis of the current casecontrol studies about the valvular and pericardial involvement in patients with Rheumatoid Arthritis (RA), asymptomatic for cardiovascular diseases.

Methods: Case-control studies were identified by searching PubMed (1975-2010) and the Cochrane Central Register of Controlled Trials (CENTRAL) (1975-2010). Participants were adult patients with RA asymptomatic for cardiovascular diseases, and the outcome measure was the presence of cardiac involvement.

Results: Quantitative synthesis included 10 relevant studies out of 2326 bibliographic citations that had been found. RA resulted significantly associated to pericardial effusion (OR 10.7; 95\% CI 5.0-23.0), valvular nodules (OR 12.5; 95\% CI 2.8-55.4), tricuspidal valve insufficiency (OR 5.3; 95\% CI 2.4-11.6), aortic valve stenosis (OR 5.2; 95\% CI 1.1-24.1), mitral valve insufficiency (OR 3.4; 95\% CI 1.7-6.7), aortic valve insufficiency (OR 1.7; 95\% CI 1.0-2.7), combined valvular alterations (OR 4.3; 95\% CI 2.3-8.0), mitral valve thickening and/or calcification (OR 5.0; 95\% CI 2.0-12.7), aortic valve thickening and/or calcification (OR 4.4; 95\% CI 1.1-17.4), valvular thickening and/or calcification (OR 4.8; 95\% CI 2.2-10.5), and mitral valve prolapse (OR 2.2; 95\% CI 1.24.0).

Conclusions: Our systematic review pointed out the strength and the grade of both pericardial and cardiac valvular involvement in RA patients. Our findings underscore the importance of an echocardiographic assessment at least in clinical research when RA patients are involved. Moreover, further research is needed to understand the possible relationship of our findings and the increased cardiovascular mortality.
\end{abstract}

(c) 2012 Elsevier Ireland Ltd. All rights reserved.

\section{Introduction}

Rheumatoid Arthritis (RA) is a chronic inflammatory disease that affects joints causing deformities, severe disability and premature mortality $[1,2]$. This disease has a high social and economic burden. Indeed, about 1.3 million adults are affected by RA in the United States [3]. The world prevalence of RA might be around $0.3-1.2 \%$ [4]. Recently the Swedish patients register [5] has shown a RA cumulative prevalence of 0.77\% (women $1.16 \%$ men $0.44 \%$ ) confirming above mentioned assumptions. In this disease, the synovial membrane is the main target, although

\footnotetext{
This work was made with the institutional, financial support of University of Palermo, Italy.

站岤 There was no relationship with industry.

* Corresponding author at: Centre of Research for Effectiveness and Appropriateness in Medicine (CREAM), Biomedical Department of Internal Medicine and Subspecialties [DiBiMIS], Piazza delle Cliniche 2, 90127 Palermo, Italy. Tel./fax: + 390916552165.

E-mail address: s.corrao@tiscali.it (S. Corrao).
}

extra-articular manifestations can be found including the cardiac ones. Pericarditis is the cardiac manifestation most readily recognized, but myocardial disease, coronary vasculitis, diastolic dysfunction, accelerated atherosclerosis and valvular lesions of the heart have also been reported [6]. The premature mortality among patients with RA is frequently due to cardiovascular disease [7], primarily ischemic heart disease [8] and congestive heart failure [9]. A recent meta-analysis of our team showed that rheumatoid patients have a higher left ventricular mass than controls [10]. Moreover, in rheumatoid patients without overt cardiovascular disease, we previously reported pericardial, valvular, and aortic root involvement that we clinically defined as "silent rheumatoid heart disease" [11]. Recently, Yiu et al. [12] have found out a significant association between Rheumatoid Arthritis and valvular calcifications. This study used multidetector computed tomography and has also pointed out that the presence of mitral valve calcification independently predicted the occurrence of premature atherosclerosis. On the other hand, several echocardiographic studies have been published in the last two decades on this issue. So that, summarizing evidence from all these studies may be useful to understand the effect of the 
disease on cardiac structures of rheumatoid patients almost partially in the pre-biological era.

The aim of our study was to perform a systematic review and meta-analysis of the current case-control studies based on echocardiographic assessment of valvular and pericardial involvement in patients with RA.

\section{Materials and methods}

\subsection{Search strategy for identification of studies}

The review was achieved following the Cochrane Collaboration Steps [13] and the Meta-analysis of Observational Studies in Epidemiology (MOOSE) standard of reporting [14].

Sources of published data included electronic database such as PubMed-Medline (1975-July 2010) [15] and the Cochrane Central Register of Controlled Trials (CENTRAL) (1975-July 2010) [16]. The search strategy was as follows: "rheumatoid arthritis AND (heart OR ventricle OR ventricular OR valvular)" without any other restriction for reaching maximum recall. We controlled for the terms "pericardial or pericardium" but it did not add any further citation recall compared to the above mentioned search string.

\subsection{Criteria for considering studies for this review}

Retrieved citations were screened independently by two adjudicators (SC, SM) using titles of papers and abstracts. Once pertinent studies (that is according to the aim of this systematic review) were identified, the full publication was retrieved and reviewed independently by the two investigators to determine the suitability for final inclusion.

The reviewers were blinded to the names of authors, institutions or journals, and articles were independently selected for inclusion according to the prespecified selection criteria. No prejudice in study evaluation was made.

The type of studies considered to be included was controlled clinical trial with case-control design. Series of case, descriptive reports, cohort and uncontrolled studies were excluded from the analysis. Participants in the studies were adult patients with $\mathrm{RA}$, asymptomatic for cardiovascular diseases.

Measured outcome was the proportion of patients with valvular and pericardial involvement.

\subsection{Quality assessments}

Methodological quality was assessed independently by two reviewers (SC, SM) using the STROBE (Strengthening the Reporting of Observational studies in Epidemiology Statement) recommendations [17], with special consideration on selection bias and detection bias. Performance bias was not considered because it concerns pharmacological studies. Moreover, loss to follow-up was not considered basing on the design of the included studies in this review (only case-control ones).

\subsection{Data extraction and statistical analysis}

Data on patients, methods, outcomes and results were extracted using a data extraction form (SM, LC). Disagreement was resolved by other adjudicator (SC). Data were analyzed using the STATA Version 9.0 and were presented as odds ratio (OR) along with their corresponding $95 \%$ confidence intervals (CI). Heterogeneity was investigated by using the $\mathrm{I}^{2}$ statistic with significance set at $\mathrm{p}<0.05$. Pooled ORs and $95 \% \mathrm{CIs}$ were calculated using a random effect model or a fixed effect model according to heterogeneity. Bias of publication was evaluated by the Egger Regression Asymmetry Test and the Regression Asymmetry Plot.

\section{Results}

The search string that we used recalled 2326 bibliographic citations. They were screened, and 55 papers were retrieved because they were recognized as pertinent. Then, 16 studies were excluded because they were not case-control studies, 1 because it was a pharmacological study and 28 because they were not pertinent. So we identified 10 relevant papers. All of them were used for this systematic review. All the patients were asymptomatic for cardiovascular disease, and, after echocardiographic assessment, none was reported affected by more than slight-moderate hemodynamic valvular alterations (as regurgitation as stenosis). Fig. 1 shows the flow-diagram of the study selection process. Appendix 1 shows characteristics of studies that were included in this systematic review [11,18-26]. Appendix 2 shows the list of studies that were excluded.

We performed a meta-analysis for each of the following abnormalities: pericardial effusion, valvular nodules, valvular thickening and/or calcification (Fig. 2), tricuspidal valve insufficiency, aortic valve insufficiency, aortic valve stenosis, mitral valve stenosis, mitral valve prolapse

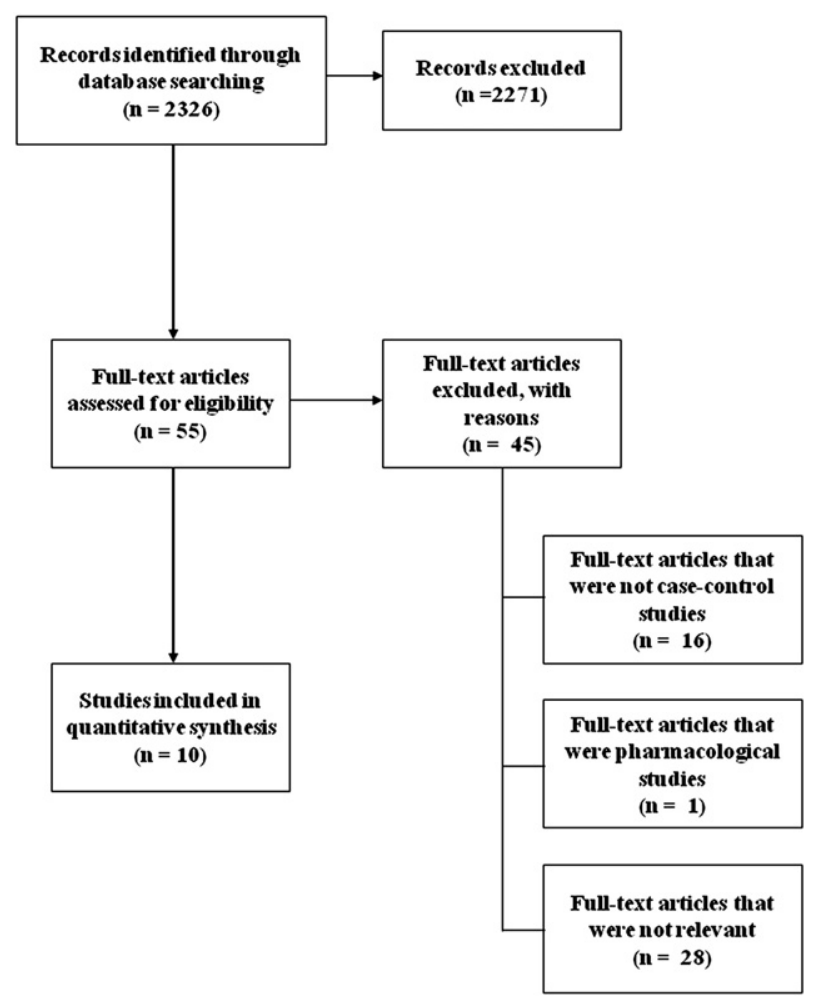

Fig. 1. Systematic review flow diagram according to the MOOSE standard: the flow chart shows the selection process regarding the retrieved citations; trials on treatment and studies not pertinent were excluded such as all the studies that were not controlled ones.

(Fig. 3), and combined valvular alterations (Fig. 4). Fig. 5 shows other four meta-analyses that were preformed about mitral valve thickening/calcification, aortic valve thickening/calcification, mitral valve prolapse, and mitral valve insufficiency. Pulmonary valve insufficiency and aortic valve prolapse were reported by only one study [18]. Thus, in this case, we did not perform any meta-analysis.

The fixed model was used for the following abnormalities: pericardial effusion, valvular nodules, valvular thickening and/or calcification, tricuspidal valve insufficiency, aortic valve insufficiency, aortic valve stenosis, mitral valve stenosis, and combined valvular alterations.

The random model was used for the following abnormalities: mitral valve insufficiency, mitral valve thickening and/or calcification, aortic valve thickening and/or calcification.

We preferred to use fixed and random models for mitral valve prolapse since the high $\mathrm{I}^{2}(51.8 \% ; \mathrm{p}<0.081)$ even if not significant.

Table 1 shows the summary data of all the performed meta-analyses, including the Egger's test statistic for evaluation of the publication bias. Only in the case of aortic valve stenosis, we found a significant $\mathrm{p}$ value by the Egger's test (this test states a probable publication bias in this field of knowledge).

Our meta-analyses showed a higher risk of pericardial effusion and valvular nodules more than ten times in patients with RA compared with controls. Concerning data about tricuspidal valve insufficiency, aortic valve stenosis, and mitral valve thickening/calcification, meta-analyses showed an increased risk about five times more in patients with RA compared with controls. Moreover, data about valvular thickening and/or calcification, combined valvular alterations, and aortic valve thickening and/ or calcification showed an increased risk about four times in patients with RA compared with controls. Data about mitral valve insufficiency showed an increased risk about three times in patients with RA compared with controls. A risk about twice in patients with RA compared with controls emerged from data about aortic valve insufficiency. Finally, data of meta-analyses did not show an increased risk about mitral valve stenosis, 


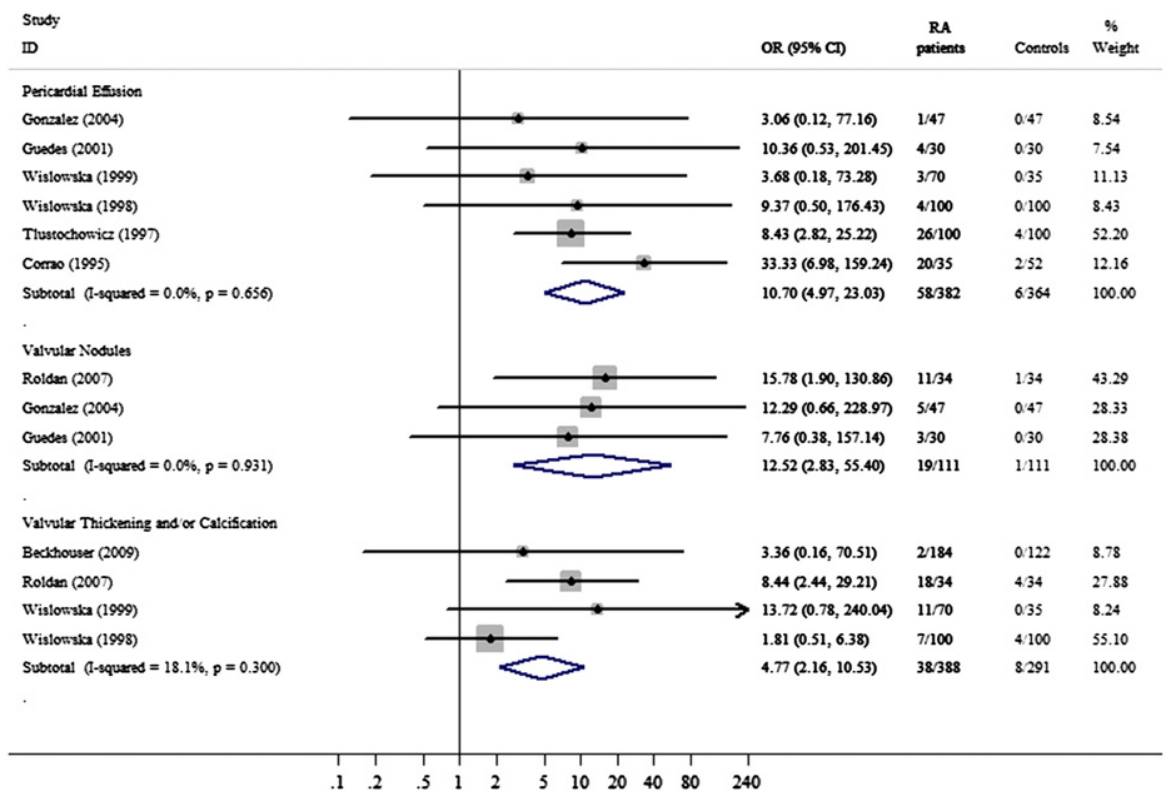

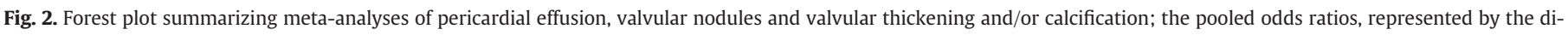

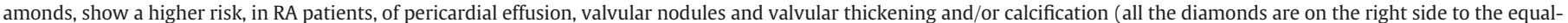
ity line).

[OR (95\% CI): 2.1 (0.7-6.9); $\mathrm{p}=0.199]$, pulmonary valve insufficiency [OR $(95 \% \mathrm{Cl}): 3.1(0.1-79.2) ; \mathrm{p}=0.494]$, and aortic valve prolapse [OR $(95 \%$ $\mathrm{CI})$ : $2.1(0.2-24.1) ; \mathrm{p}=0.561]$ in patients with $\mathrm{RA}$ compared with controls. About mitral valve prolapse, the meta-analysis showed a high grade of heterogeneity $\left(\mathrm{I}^{2}=51.8 \%\right)$ even though it did not result significant [OR (95\% CI): 2.2(0.8-6.1); $\mathrm{p}=0.081]$ : in this case, we performed a

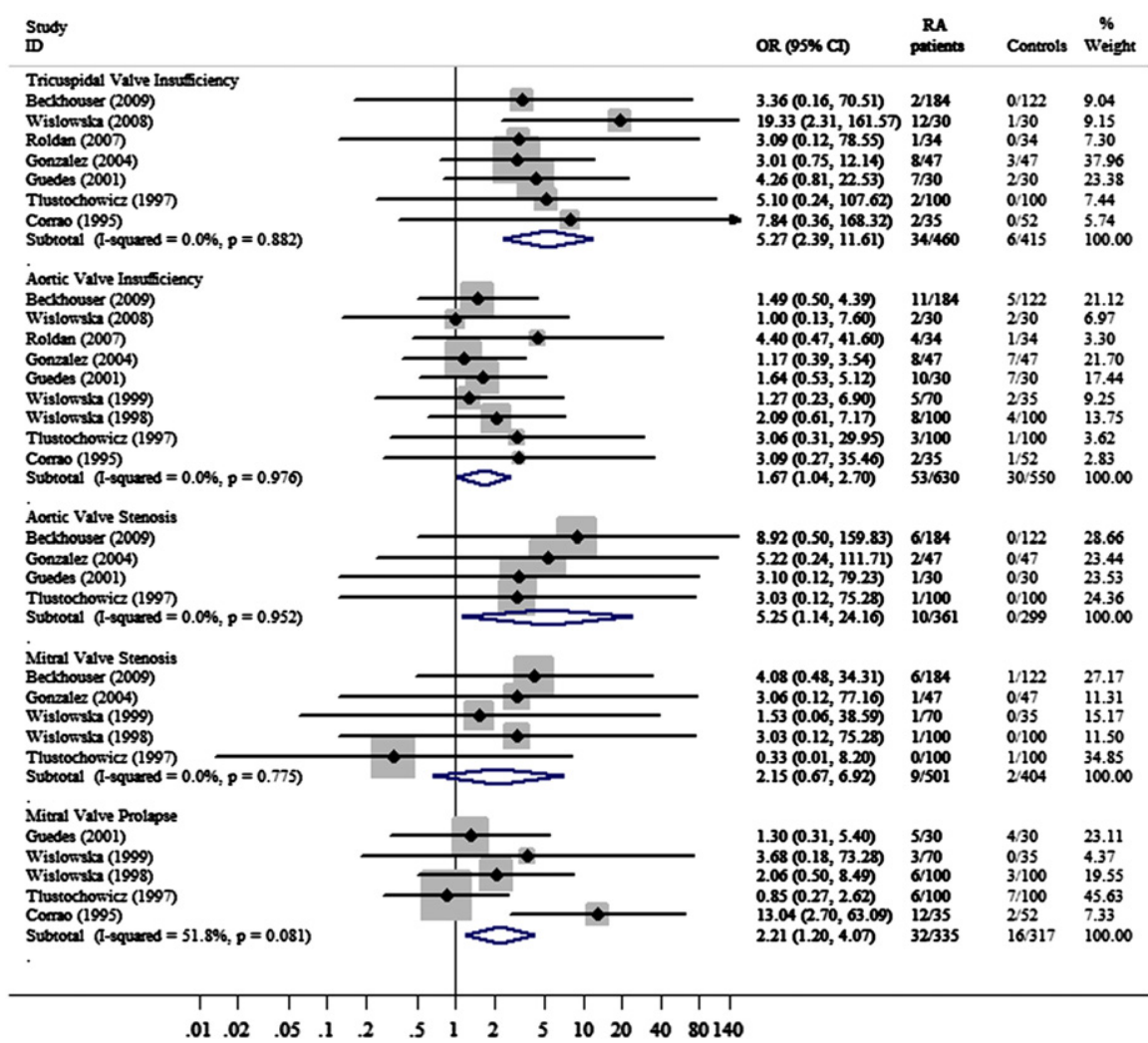

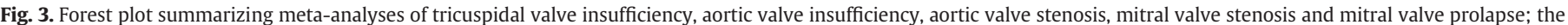

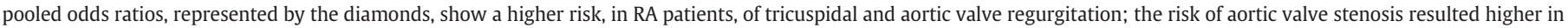

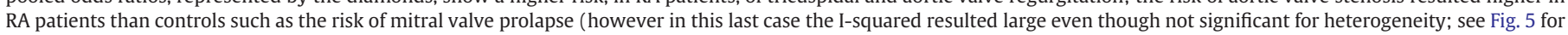
the same meta-analysis on mitral valve prolapse applying the random-effect model). 


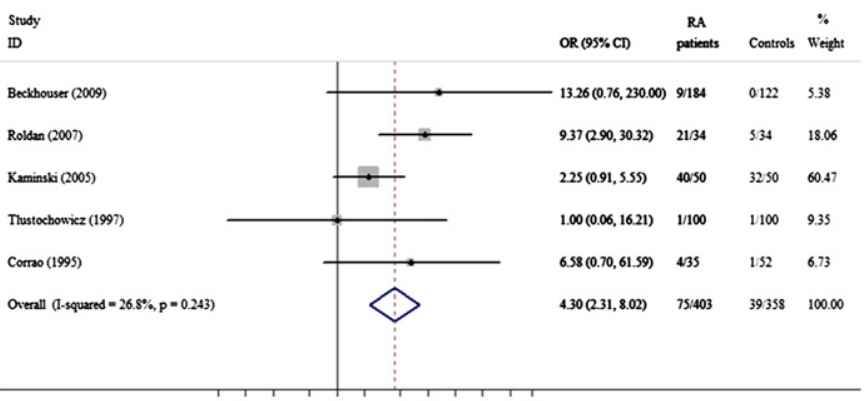

$\begin{array}{llllllllllll}.05 & 1 & 2 & . & 5 & 1 & 2 & 5 & 10 & 20 & 40 & 80140\end{array}$

Fig. 4. Forest plot of combined valvular alteration; the pooled odds ratio, represented by the diamond, shows a higher risk, in RA patients, of combined valvular alteration (the diamond is on the right side to the equality line).

sensitive analysis using both the models (fixed and random); the two analyses showed different results with a potentially double risk in patients with RA compared with controls (Table 1).

\section{Discussion}

Various significant cardiac alterations have been detected by echocardiography in RA patient with no cardiac symptoms and/or clinical evidence of extra cardiac complaints. The extra-articular inflammatory process seems to involve the pericardium frequently and insidiously, even in the absence of symptoms. In fact, pericardial effusion is the most frequent abnormality, and it has been described as minimal pericardial effusion (end-diastolic pericardial-epicardial separation up to
$4 \mathrm{~mm}$ ) or overt pericardial effusion (end-diastolic pericardial-epicardial separation more than $4 \mathrm{~mm}$ ) [11].

The other main alterations are mitral and aortic valve thickening, mitral valve prolapse with or without insufficiency, isolated valvular insufficiency and aortic root abnormalities [11], (i.e. enlargement of almost one sinus of Valsalva). Abnormal valve echoes in RA patients might be due to fibrosis of the valve structures for extra-articular inflammatory process [11]. Beyond these valvular alterations, left ventricular diastolic filling abnormalities have been observed in spite of normal left ventricular systolic function. This might be clinically very important because diastolic dysfunction has been recognized as a primary cause of congestive heart failure that is highly prevalent in RA patients. In these patients, diastolic dysfunction seems to be related with structural abnormalities of the left ventricle, in particular with changes regarding left ventricular mass, interventricular septum thickening and posterior wall thickening [27]. Also, Rudominer et al., in a recent study, have described the association between AR and an increased left ventricular mass [28], and this increase has been confirmed by our recent metaanalysis [10].

Thus, five alterations at least seem to be typical of RA patients without any symptom of cardiac disease: 1) pericardial effusion, 2) valvular thickening and nodules, 3) isolated valvular insufficiency, 4) aortic root alteration, and 5) structural (increased left ventricular mass) and functional (diastolic dysfunction) left ventricular changes. These changes are variously combined in each patient. Hence, we believed that it is possible to represent this heart involvement such as "silent rheumatoid heart disease". On the other hand, abnormalities in left ventricular myocardial structure and diastolic function are clinically very important. Indeed, these abnormalities are also correlated to a higher risk of both cardiac failure and cardiovascular mortality in patients with RA. However, these

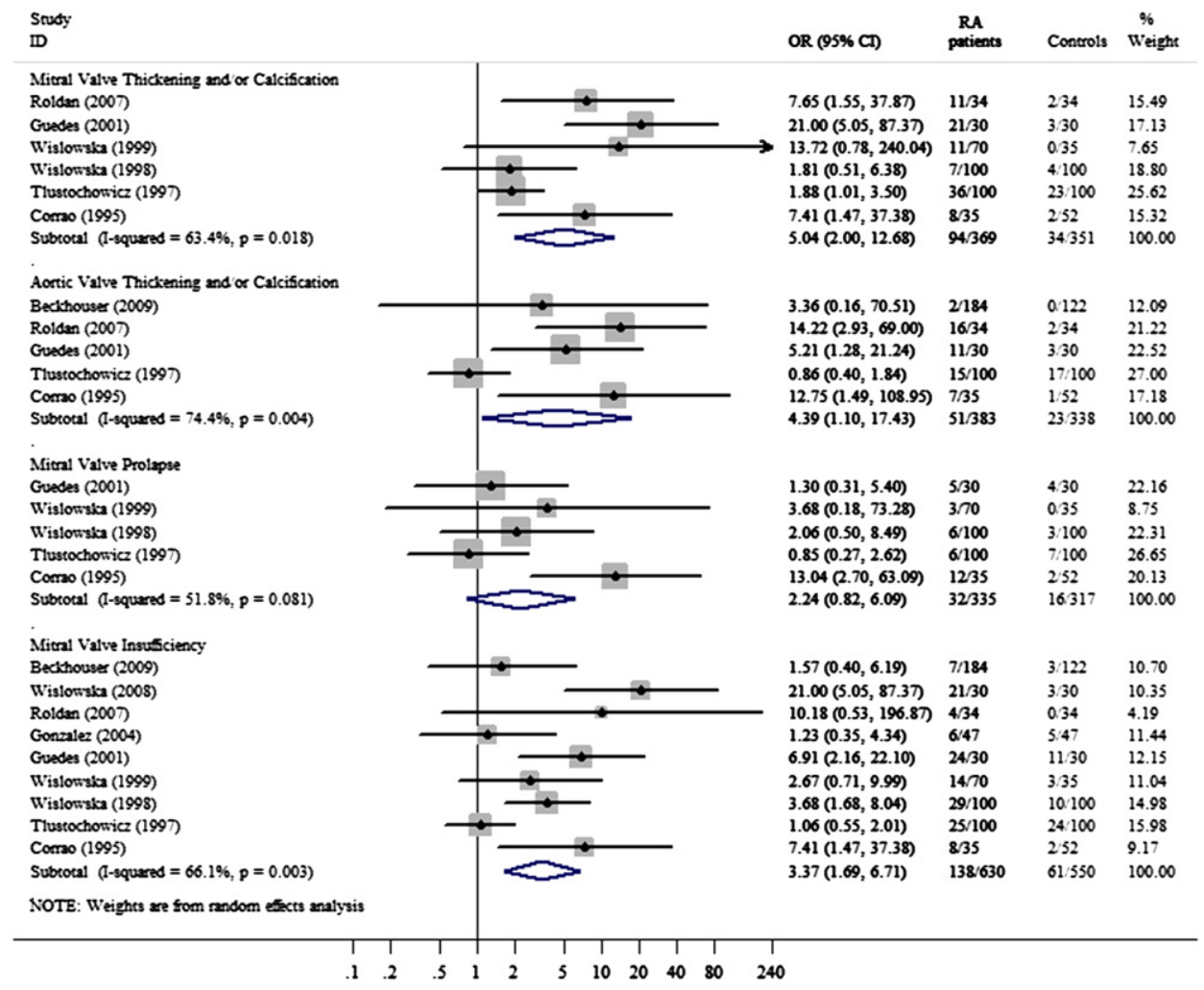

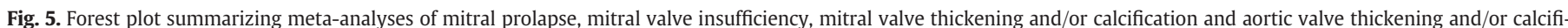

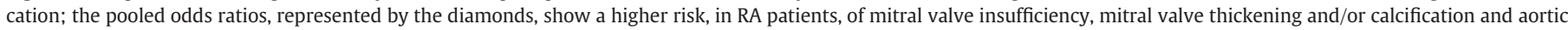

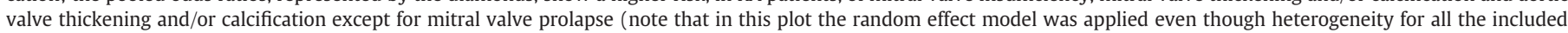
studies did not result to a statistical significance; see Fig. 3 for the same meta-analysis on mitral valve prolapse applying the fixed-effect model). 
Table 1

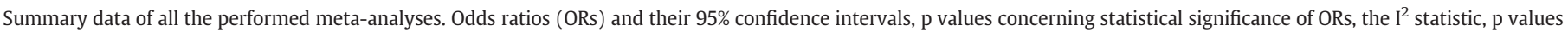
concerning heterogeneity, and p values of the Egger's test are shown. The Egger's test represents the statistic to evaluate publication bias.

\begin{tabular}{|c|c|c|c|c|c|}
\hline Ecocardiographic abnormalities & Pooled $\mathrm{OR}^{\mathrm{a}}\left(95 \% \mathrm{Cl}^{\mathrm{b}}\right)$ & $\mathrm{p}$ & $\mathrm{I}^{2 \mathrm{c}}(\%)$ & $\mathrm{p}$ (heterogeneity) & $\begin{array}{l}\text { Egger's test }^{\mathrm{d}} \\
\mathrm{p}\end{array}$ \\
\hline Pericardial effusion & $10.698(4.969-23.033)$ & 0.000 & 0.0 & 0.656 & 0.746 \\
\hline Valvular nodules & $12.518(2.828-55.404)$ & 0.001 & 0.0 & 0.931 & 0.283 \\
\hline Valvular thickening and/or calcification & $4.773(2.163-10.534)$ & 0.000 & 18.1 & 0.300 & 0.702 \\
\hline Mitral valve insufficiency & $3.369(1.691-6.710)$ & 0.001 & 66.1 & 0.003 & 0.178 \\
\hline Tricuspidal valve insufficiency & $5.265(2.388-11.609)$ & 0.000 & 0.0 & 0.882 & 0.727 \\
\hline Aortic valve insufficiency & $1.673(1.036-2.703)$ & 0.035 & 0.0 & 0.976 & 0.069 \\
\hline Pulmonary valve insufficiency ${ }^{\mathrm{e}}$ & $3.102(0.121-79.228)$ & 0.494 & n.a. ${ }^{\mathrm{f}}$ & n.a. ${ }^{f}$ & n.a. ${ }^{f}$ \\
\hline Aortic valve stenosis & $5.249(1.140-24.165)$ & 0.033 & 0.0 & 0.952 & 0.009 \\
\hline Mitral valve stenosis & $2.151(0.669-6.916)$ & 0.199 & 0.0 & 0.775 & 0.153 \\
\hline Mitral valve prolapse (fixed effect model) & $2.208(1.200-4.065)$ & 0.011 & 51.8 & 0.081 & 0.613 \\
\hline Mitral valve prolapse (random effect model) & $2.241(0.825-6.091)$ & 0.114 & 51.8 & 0.081 & 0.613 \\
\hline Aortic valve prolapse $\mathrm{e}^{\mathrm{e}}$ & $2.071(0.178-24.148)$ & 0.561 & n.a. ${ }^{\mathrm{f}}$ & n.a. ${ }^{f}$ & n.a. ${ }^{\mathrm{f}}$ \\
\hline Combined valvular alterations & $4.303(2.310-8.018)$ & 0.000 & 26.8 & 0.243 & 0.552 \\
\hline Mitral valve thickening and/or calcification & $5.038(2.002-12.680)$ & 0.001 & 63.4 & 0.018 & 0.182 \\
\hline Aortic valve thickening and/or calcification & $4.386(1.104-17.430)$ & 0.036 & 74.4 & 0.004 & 0.212 \\
\hline
\end{tabular}

a OR: odds ratio.

b $\mathrm{CI}=$ confidence interval.

c $\mathrm{I}^{2}=$ as a measure of statistical heterogeneity.

d Egger's test for publication bias.

e Only one study was recognized.

${ }^{\mathrm{f}}$ n.a. $=$ not assessable.

aspects related to the left ventricle structure and function, although very important, were not the object of this systematic review, but further investigation about this issue is hoped for completing the whole picture of the heart involvement in RA.

The results of this systematic review with meta-analysis have shown some unclear areas of literature about pulmonary valve insufficiency and aortic valve prolapse (investigated by only one study), and aortic valve stenosis (publication bias was detected). Another gray zone regards mitral valve prolapse. Indeed, we found an intermediate grade of heterogeneity that involved contrasting results when different meta-analysis models were applied. While, according to the findings of this systematic review, data are substantially strong concerning an increased risk of both pericardial involvement and aortic and mitral valvular alterations in RA patients compared to healthy controls. In particular, there was a strong evidence of pericardial effusion and mitral or aortic regurgitation as well as valvular nodules and isolated or combined valvular thickening/ calcifications. Moreover, our systematic review fits with clinical studies recruiting patients mainly followed-up in the pre-biological drug era. This represents a chance to evaluate actual effects on the heart of the underlying phlogistic rheumatoid process without shadowing by the powerful biological drugs. On the other hand, the paramount importance of our findings lies in the fact that the presence of aortic and mitral valvular calcifications has been associated with cardiovascular events in the general population [29,30]. Indeed, Yiu et al. recently [12] demonstrated that cardiac valvular calcifications in patients with RA and Systemic Lupus
Erythematosus predict the occurrence of premature atherosclerosis with arterial calcification. For the first time, our systematic review has documented the grade and strength of the association between pericardial and cardiac valvular alterations, in particular valvular calcifications, and RA. These findings could be very useful for further research that would explain the highest cardiovascular morbidity and mortality in this kind of patients.

In conclusion, we found a significant valvular and pericardial involvement in RA patients compared with control samples. All seems to represent the cardiac expression of the same underlying phlogistic process typical of RA disease. This should be considered a cornerstone for future research in the field of RA where echocardiographic assessment should be considered as part of the instrumental assessment of the recruited patients. However, further research is needed to understand the possible relationship of our findings and the increased cardiovascular mortality in this kind of patients. Finally, we think that the knowledge of presence and kind of unrecognized cardiac abnormalities in asymptomatic patients might be important for the correct management of RA patients.

\section{Acknowledgment}

The authors of this manuscript have certified that they comply with the Principles of Ethical Publishing in the International Journal of Cardiology [31].

Appendix 1. Characteristics of the studies included in the quantitative synthesis

\begin{tabular}{|c|c|c|c|}
\hline $\begin{array}{l}\text { Author, } \\
\text { publication } \\
\text { year, country }\end{array}$ & Design & Study's objective & Participants \\
\hline $\begin{array}{l}\text { Beckhauser } \\
\text { AP et al. } \\
\text { 2009, Brazil }\end{array}$ & $\begin{array}{l}\text { Case- } \\
\text { control }\end{array}$ & $\begin{array}{l}\text { To verify the frequency of valvular heart involvement } \\
\text { in Rheumatoid Arthritis patients by trans-thoracic } \\
\text { echocardiographic examination. }\end{array}$ & $\begin{array}{l}184 \text { rheumatoid patients } \\
\text { ( } 17 \text { men, } 167 \text { women; mean age } 48.2 \pm 13.9 \text { yrs; mean duration of } \\
\text { disease } 8.4 \pm 7.4 \text { yrs) from the Rheumatology Unit of Hospital Evangelico de Curtiba; } \\
122 \text { controls ( } 18 \text { men, } 104 \text { women; mean age } 51.5 \pm 14.4 \text { yrs). }\end{array}$ \\
\hline $\begin{array}{l}\text { Wislowska M } \\
\text { et al. 2008, } \\
\text { Poland }\end{array}$ & $\begin{array}{l}\text { Case- } \\
\text { control }\end{array}$ & $\begin{array}{l}\text { To assess systolic and diastolic function of the left } \\
\text { ventricle in Rheumatoid Arthritis patients, by } \\
\text { trans-thoracic echocardiographic examination, and } \\
\text { also estimate whether there is a correlation between the } \\
\text { duration and severity of Rheumatoid Arthritis and } \\
\text { the degree of left ventricle diastolic dysfunction. }\end{array}$ & $\begin{array}{l}30 \text { rheumatoid patients } \\
\text { ( } 5 \text { men, } 25 \text { women; mean age } 51.8 \pm 7.6 \text { yrs; mean duration of disease } 12.5 \pm 9.3 \text { yrs) } \\
\text { from the Rheumatologic Outpatient Department of the central clinical hospital in Warsaw; } \\
30 \text { controls ( } 5 \text { men, } 25 \text { women; mean age } 51.7 \pm 7.6 \text { yrs). }\end{array}$ \\
\hline
\end{tabular}


Appendix 1 (continued)

\begin{tabular}{|c|c|c|c|}
\hline $\begin{array}{l}\text { Author, } \\
\text { publication } \\
\text { year, country }\end{array}$ & Design & Study's objective & Participants \\
\hline $\begin{array}{l}\text { Roldan CA et } \\
\text { al. 2007, } \\
\text { New Mexico }\end{array}$ & $\begin{array}{l}\text { Case- } \\
\text { control }\end{array}$ & $\begin{array}{l}\text { To characterize valvular heart disease associated } \\
\text { with Rheumatoid Arthritis by trans-esophageal } \\
\text { echocardiography. }\end{array}$ & $\begin{array}{l}34 \text { rheumatoid patients } \\
\text { ( } 15 \text { men, } 19 \text { women; mean age } 50 \pm 10 \mathrm{yrs} \text {; mean duration of disease } 13 \pm 7 \mathrm{yrs} \text { ) } \\
\text { from the University of New Mexico Health Science Center in Albuquerque; } \\
34 \text { controls ( } 16 \text { men, } 18 \text { women; mean age } 42 \pm 6 \text { yrs). }\end{array}$ \\
\hline $\begin{array}{l}\text { Kamiński G } \\
\text { et al. } 2005 \text {, } \\
\text { Poland }\end{array}$ & $\begin{array}{l}\text { Case- } \\
\text { control }\end{array}$ & $\begin{array}{l}\text { To assess the effect of rheumatoid process on the } \\
\text { heart in patients with Rheumatoid Arthritis without } \\
\text { clinically over features of heart disease by trans- } \\
\text { thoracic echocardiographic examination. }\end{array}$ & $\begin{array}{l}50 \text { rheumatoid patients } \\
(6 \text { men, } 44 \text { women; mean age } 59.4 \pm 11.1 \text { yrs; mean duration of disease } 10.7 \pm 8.7 \mathrm{yrs} \text { ) } \\
\text { in Warsaw; } \\
50 \text { controls ( } 6 \text { men, } 44 \text { women; mean age } 59.2 \pm 11.2 \text { yrs). }\end{array}$ \\
\hline $\begin{array}{l}\text { Gonzalez- } \\
\text { Juanatey C } \\
\text { et al. 2004, } \\
\text { Spain }\end{array}$ & $\begin{array}{l}\text { Case- } \\
\text { control }\end{array}$ & $\begin{array}{l}\text { To assess the frequency of structural and functional } \\
\text { abnormalities in long-term treated Rheumatoid } \\
\text { Arthritis patients without clinically evident } \\
\text { cardiovascular manifestation, by trans-thoracic } \\
\text { echocardiographic examination. }\end{array}$ & $\begin{array}{l}47 \text { rheumatoid patients } \\
\text { ( } 11 \text { men, } 35 \text { women; mean age } 59.2 \pm 12.5 \mathrm{yrs} \text {; mean duration of disease } 15.5 \pm 8.5 \mathrm{yrs} \text { ) } \\
\text { from the Hospital Xeral-Calde, Lugo, in Northwest Spain; } \\
47 \text { controls ( } 11 \text { men, } 36 \text { women; mean age } 58.6 \pm 12.4 \mathrm{yrs} \text { ). }\end{array}$ \\
\hline $\begin{array}{l}\text { Guedes C et al. } \\
\text { 2001, France }\end{array}$ & $\begin{array}{l}\text { Case- } \\
\text { control }\end{array}$ & $\begin{array}{l}\text { To assess the frequency and type of heart lesions in } \\
\text { Rheumatoid Arthritis, coupling trans-thoracic } \\
\text { echocardiography with trans-esophageal one. }\end{array}$ & $\begin{array}{l}30 \text { rheumatoid patients } \\
\text { ( } 4 \text { men, } 26 \text { women; mean age } 57.8 \pm 15.1 \text { yrs; mean duration of disease } 11 \pm 8.7 \text { yrs) } \\
\text { from the Rheumatology Department of the Bobigny-Avicenne Teaching Hospital, France; } \\
30 \text { controls ( } 4 \text { men, } 26 \text { women; mean age } 57.8 \pm 15.0 \text { yrs). }\end{array}$ \\
\hline $\begin{array}{l}\text { Wislowka M } \\
\text { et al. 1999, } \\
\text { Poland }\end{array}$ & $\begin{array}{l}\text { Case- } \\
\text { control }\end{array}$ & $\begin{array}{l}\text { To assess cardiac abnormalities in two groups of } \\
\text { Rheumatoid Arthritis patients, nodular and non } \\
\text { nodular, by trans-thoracic echocardiographic } \\
\text { examination. }\end{array}$ & $\begin{array}{l}35 \text { nodular rheumatoid patients and } 35 \text { non nodular ones } \\
\text { ( } 14 \text { men, } 56 \text { women; mean age } 53.4 \pm 9.4 \text { yrs; mean duration of disease } 9.4 \pm 6.7 \text { yrs) } \\
\text { from the Rheumatology Outpatient Department of the Central Clinical Hospital } \\
\text { in Warsaw; } \\
35 \text { controls with osteoarthrosis and spondyloarthrosis ( } 7 \text { men, } 28 \text { women; } \\
\text { mean age } 53.3 \pm 9.4 \text { yrs). }\end{array}$ \\
\hline $\begin{array}{l}\text { Wislowska M } \\
\text { et al. 1998, } \\
\text { Poland }\end{array}$ & $\begin{array}{l}\text { Case- } \\
\text { control }\end{array}$ & $\begin{array}{l}\text { To assess cardiac abnormalities in Rheumatoid } \\
\text { Arthritis patients by echocardiographic examination. }\end{array}$ & $\begin{array}{l}100 \text { rheumatoid patients } \\
\text { ( } 18 \text { men, } 82 \text { women; mean age } 49.9 \pm 11.3 \text { yrs; mean duration of disease } 9.4 \pm 6.7 \mathrm{yrs} \text { ) } \\
\text { from the Rheumatology Outpatient Department of the Central Clinical Hospital } \\
\text { in Warsaw; } \\
100 \text { controls with osteoarthrosis ( } \mathrm{n} .8 \text { ) and spondyloarthrosis ( } \mathrm{n} .92 \text { ) } \\
\text { (18 men, } 82 \text { women; mean age } 49.8 \pm 11.1 \mathrm{yrs} \text { ). }\end{array}$ \\
\hline $\begin{array}{l}\text { Tlustochowicz } \\
\text { W et al. } 1997 \text {, } \\
\text { Poland }\end{array}$ & $\begin{array}{l}\text { Case- } \\
\text { control }\end{array}$ & $\begin{array}{l}\text { To assess the clinical significance of heart lesions in } \\
\text { Rheumatoid Arthritis patients by trans-thoracic } \\
\text { echocardiographic examination. }\end{array}$ & $\begin{array}{l}100 \text { rheumatoid patients } \\
\text { ( } 23 \text { men, } 77 \text { women; mean age } 55.7 \pm 12.5 \mathrm{yrs} \text {; mean duration of disease } 8.3 \pm 8.0 \mathrm{yrs} \text { ) } \\
\text { from the University Hospital of Warsaw; } \\
100 \text { controls ( } 23 \text { men, } 77 \text { women; mean age } 55.7 \pm 12.7 \mathrm{yrs} \text { ). }\end{array}$ \\
\hline $\begin{array}{l}\text { Corrao S et al. } \\
1995 \text {, Italy }\end{array}$ & $\begin{array}{l}\text { Case- } \\
\text { control }\end{array}$ & $\begin{array}{l}\text { To determine the nature and extent of cardiac } \\
\text { involvement in Rheumatoid Arthritis patients with } \\
\text { no symptoms of cardiac disease by trans-thoracic } \\
\text { echocardiographic examination. }\end{array}$ & $\begin{array}{l}35 \text { rheumatoid patients } \\
(5 \text { men, } 25 \text { women; mean age } 51 \pm 11 \text { yrs; mean duration of disease } 5 \pm 8 \text { yrs) } \\
\text { from Rheumatological outpatient clinic in Palermo; } \\
52 \text { controls ( } 7 \text { men, } 45 \text { women, mean age } 51 \pm 12 \text { yrs). }\end{array}$ \\
\hline
\end{tabular}

\section{Appendix 2. Excluded studies and the reason of exclusion}

\begin{tabular}{|c|c|c|c|}
\hline \multicolumn{2}{|c|}{ Author, publication year } & \multirow{2}{*}{$\begin{array}{l}\text { Title } \\
\text { Cardiac and pulmonary alterations in patients with Rheumatoid Arthritis. }\end{array}$} & \multirow{2}{*}{$\begin{array}{l}\text { Reason of } \\
\text { exclusion }\end{array}$} \\
\hline 1 & Berisha I, Berisha B, Krasniqi X, 2010 & & \\
\hline 2 & $\begin{array}{l}\text { Obradović-Tomasević B, Vujasinović-Stupar N, } \\
\text { Tomasević R, } 2009\end{array}$ & The assessment of diastolic function in patients with Rheumatoid Arthritis. & $\begin{array}{l}\text { Not case-control } \\
\text { study }\end{array}$ \\
\hline 3 & $\begin{array}{l}\text { Sugiura T, Kumon Y, Kataoka H, Matsumura Y, Takeuchi H, } \\
\text { Doi Y, } 2008\end{array}$ & Asymptomatic pericardial effusion in patients with Rheumatoid Arthritis. & $\begin{array}{l}\text { Not case-control } \\
\text { study }\end{array}$ \\
\hline 4 & Dawson JK, Goodson NG, Graham DR, Lynch MP, 2000 & $\begin{array}{l}\text { Raised pulmonary artery pressures measured with Doppler echocardiography } \\
\text { in Rheumatoid Arthritis patients. }\end{array}$ & $\begin{array}{l}\text { Not case-control } \\
\text { study }\end{array}$ \\
\hline 5 & $\begin{array}{l}\text { Nemchinov EN, Kanevskaia MZ, Chichasova NV, Telepneva LM, } \\
\text { Krel' AA, } 1994\end{array}$ & $\begin{array}{l}\text { Heart defects in Rheumatoid Arthritis patients (the results of a multiyear } \\
\text { prospective clinico-echocardiographic study). }\end{array}$ & $\begin{array}{l}\text { Not case-control } \\
\text { study }\end{array}$ \\
\hline 6 & Rowe IF, Gibson DG, Keat AC, Brewerton DA, 1991 & $\begin{array}{l}\text { Echocardiographic diastolic abnormalities of the left ventricle in inflammatory } \\
\text { joint disease. }\end{array}$ & $\begin{array}{l}\text { Not case-control } \\
\text { study }\end{array}$ \\
\hline 7 & Kelly CA, Bourke JP, Malcolm A, Griffiths ID, 1990 & $\begin{array}{l}\text { Chronic pericardial disease in patients with Rheumatoid Arthritis: a longitudinal } \\
\text { study. }\end{array}$ & $\begin{array}{l}\text { Not case-control } \\
\text { study }\end{array}$ \\
\hline 8 & Mody GM, Stevens JE, Meyers OL, 1987 & The heart in Rheumatoid Arthritis: a clinical and echocardiographic study. & $\begin{array}{l}\text { Not case-control } \\
\text { study }\end{array}$ \\
\hline 9 & Badui E, Jiménez J, Saldivar C, Mintz G, Lavalle C, Fraga A, 1987 & The heart and Rheumatoid Arthritis. Prospective study of 100 cases. & $\begin{array}{l}\text { Not case-control } \\
\text { study }\end{array}$ \\
\hline 10 & $\begin{array}{l}\text { Kozáková M, Hradec J, Petrásek J, Kölbel F, Urbanová M, } \\
\text { Dostál C, } 1985\end{array}$ & Cardiac involvement in progressive polyarthritis: an echocardiographic study. & $\begin{array}{l}\text { Not case-control } \\
\text { study }\end{array}$ \\
\hline 11 & Svantesson H, Björkhem G, Elborgh R, 1983 & Cardiac involvement in juvenile Rheumatoid Arthritis. A follow-up study. & $\begin{array}{l}\text { Not case-control } \\
\text { study }\end{array}$ \\
\hline 12 & Nomeir AM, Turner RA, Watts LE, 1979 & Cardiac involvement in Rheumatoid Arthritis. Follow-up study. & $\begin{array}{l}\text { Not case-control } \\
\text { study }\end{array}$ \\
\hline
\end{tabular}


Appendix 2 (continued)

Author, publication year

Title

Reason of

exclusion

13 Devlin AB, Goldstraw P, Caves PK, 1978

14 David-Chaussé J, Blanchot P, Warin J, Dehais J, Bullier R, Texier JM, 1976

15 Thadani U, Iveson JM, Wright V, 1975

16 Okada T, Shiokawa Y, 1975

17 Ikonomidis I, Lekakis JP, Nikolaou M, Paraskevaidis I, Andreadou I, Kaplanoglou T, Katsimbri P, Skarantavos G, Soucacos PN, Kremastinos DT, 2008

18 Liang KP, Myasoedova E, Crowson CS, Davis JM, Roger VL, Karon BL, Borgeson DD, Therneau TM, Rodeheffer RJ, Gabriel SE, 2010

19 Rudominer RL, Roman MJ, Devereux RB, Paget SA, Schwartz JE, Lockshin MD, Crow MK, Sammaritano L, Levine DM, Salmon JE, 2009

20 Yavasoglu I, Senturk T, Onbasili A, 2008

21 Yazici D, Tokay S, Aydin S, Toprak A, Inanc N, Khan SR, Fak AS, Direskeneli H, 2008

22 Meune C, Wahbi K, Assous N, Weber S, Kahan A Allanore Y, 2007

23 Udayakumar N, Venkatesan S, Rajendiran C, 2007

24 Birdane A, Korkmaz C, Ata N, Cavusoglu Y, Kasifoglu T, Dogan SM, Gorenek B, Goktekin O, Unalir A, Timuralp B, 2007

25 Guler H, Seyfeli E, Sahin G, Duru M, Akgul F, Saglam H, Yalcin F, 2007

26 Krasnosel'skǐ MIa, Bratanova MZ, Polupan AA, Tsurko VV, 2007

27 Nemchinov EN, 2006

28 Rexhepaj N, Bajraktari G, Berisha I, Beqiri A, Shatri F, Hima F, Elezi S, Ndrepepa G, 2006

29 Seyfeli E, Guler H, Akoglu S, Karazincir S, Akgul F, Saglam H, Seydaliyeva T, Yalcin F, 2006

30 Canturk F, Yazici M, Alayli G, Menekse EB, Demircan S, Ibrahimli F, Menekse S, 2006

31 Arslan S, Bozkurt E, Sari RA, Erol MK, 2006

32 Arslan S, Bozkurt E, Sari RA, Erol MK, 2006

33 Bharti BB, Kumar S, Kapoor A, Agarwal A, Mishra R Sinha N, 2004

34 Yildiz M, Soy M, Kurum T, Ozbay G, 2004

35 Levendoglu F, Temizhan A, Ugurlu H, Ozdemir A, Yazici M, 2004

36 Kamiński G, Cholewa M, Tłustochowicz W, Cwetsch A, Skrobowski A, Dziuk M, 2003

37 Alpaslan M, Onrat E, Evcik D, 2003

38 Klocke R, Cockcroft JR, Taylor GJ, Hall IR, Blake DR, 2003

39 Oguz D, Ocal B, Ertan U, Narin H, Karademir S, Senocak F, 2000

40 Di Franco M, Paradiso M, Mammarella A, Paoletti V, Labbadia G, Coppotelli L,Taccari E, Musca A, 2000

41 Montecucco C, Gobbi G, Perlini S, Rossi S, Grandi AM, Caporali R, Finardi G, 1999

42 Corrao S, Sallì L, Arnone $\mathrm{S}$, Scaglione R, Pinto $\mathrm{A}$, Licata G, 2006

43 Tłustochowicz W, Piotrowicz R, Cwetsch A, Raczka A, Kramarz E, Nowak J, 1995

44 Mustonen J, Laakso M, Hirvonen T, Mutru O, Pirnes M, Vainio P, Kuikka JT, Rautio P, Länsimies E, 1993

45 Del Real-More O, Villavicencio R, Iglesias-Gamarra A, Pena MA, Cueto L, Arriaga-Gracia J, Alarcon-Segovia D, 1983
Aortic valve replacement in rheumatoid aortic incompetence.

Atrioventricular blocks and Rheumatoid Arthritis.

Cardiac tamponade, constrictive pericarditis and pericardial resection in Rheumatoid Arthritis.

Cardiac lesions in collagen disease.

Inhibition of interleukin-1 by anakinra improves vascular and left ventricular function in patients with Rheumatoid Arthritis.

Increased prevalence of diastolic dysfunction in Rheumatoid Arthritis.

Independent association of Rheumatoid Arthritis with increased left ventricular mass but not with reduced ejection fraction.

Diastolic dysfunction in Rheumatoid Arthritis and duration of disease.

Echocardiographic evaluation of cardiac diastolic function in patients with

Rheumatoid Arthritis: 5 years of follow-up.

Myocardial dysfunction in Rheumatoid Arthritis: a controlled tissue-Doppler echocardiography study.

Diastolic function abnormalities in Rheumatoid Arthritis: relation with duration of disease.

Tissue Doppler imaging in the evaluation of the left and right ventricular diastolic functions in Rheumatoid Arthritis.

P wave dispersion in patients with Rheumatoid Arthritis: its relation with clinical and echocardiographic parameters.

Tissue dopplerography of the myocardium in diagnosis of myocardial involvement in patients with Rheumatoid Arthritis.

The functional condition of the left ventricle in patients suffering from Rheumatoid Arthritis with subcutaneous rheumatoid nodules.

Left and right ventricular diastolic functions in patients with Rheumatoid Arthritis without clinically evident cardiovascular disease.

Right ventricular diastolic abnormalities in Rheumatoid Arthritis and its relationship with left ventricular and pulmonary involvement. A tissue Doppler echocardiographic study.

Combined use of propagation velocity and intraventricular dispersion of $\mathrm{E}$ wave velocity for the evaluation of diastolic functions in patients with Rheumatoid Arthritis.

Diastolic function abnormalities in active Rheumatoid Arthritis evaluation by conventional Doppler and tissue Doppler: relation with duration of disease. Use of tissue Doppler and its comparison with other conventional Doppler techniques in the assessment of diastolic functions in patients with active Rheumatoid Arthritis.

Assessment of left ventricular systolic and diastolic function in juvenile Rheumatoid Arthritis.

Increased pulse wave velocity and shortened pulse wave propagation time in young patients with Rheumatoid Arthritis.

Ventricular function abnormalities in active Rheumatoid Arthritis: a Doppler echocardiographic study.

Left ventricular function in Rheumatoid Arthritis patients.

Doppler echocardiographic evaluation of ventricular function in patients with Rheumatoid Arthritis.

Arterial stiffness and central blood pressure, as determined by pulse wave analysis, in Rheumatoid Arthritis.

Left ventricular diastolic functions in juvenile Rheumatoid Arthritis.

Diastolic function abnormalities in Rheumatoid Arthritis. Evaluation by echo Doppler transmitral flow and pulmonary venous flow: relation with duration of disease.

Impaired diastolic function in active Rheumatoid Arthritis. Relationship with disease duration.

Echo-Doppler left ventricular filling abnormalities in patients with

Rheumatoid Arthritis without clinically evident cardiovascular disease.

24-h ECG monitoring in patients with Rheumatoid Arthritis.

Abnormalities in left ventricular diastolic function in male patients with Rheumatoid Arthritis without clinically evident cardiovascular disease.

Echocardiographic evaluation of patients with Rheumatoid Arthritis.
Not case-contro

study

Not case-contro

study

Not case-control

study

Not case-control

study

Pharmacological

study

Not pertinent

Not pertinent

Not pertinent

Not pertinent

Not pertinent

Not pertinent

Not pertinent

Not pertinent

Not pertinent

Not pertinent

Not pertinent

Not pertinent

Not pertinent

Not pertinent

Not pertinent

Not pertinent

Not pertinent

Not pertinent

Not pertinent

Not pertinent

Not pertinent

Not pertinent

Not pertinen

Not pertinent

Not pertinent

Not pertinent

Not pertinent

Not pertinent 


\section{References}

[1] Isomaki H. Long-term outcome of rheumatoid arthritis. Scand J Rheumatol Suppl 1992;95:3-8.

[2] Wolfe F. The natural history of rheumatoid arthritis. J Rheumatol Suppl 1996;44: $13-22$.

[3] Helmick CG, Felson DT, Lawrence RC, et al. Estimates of the prevalence of arthritis and other rheumatic conditions in the United States. Arthritis Rheum 2008;58: $15-25$.

[4]. Rheumatoid arthritisSilman AJ, Horchberg MC, editors. Epidemiology of the rheumatic diseases. Oxford: Oxford Medical Publications; 1993. p. 7-68.

[5] Neovius M, Simard JF, Askling J; ARTIS study group. Nationwide prevalence of rheumatoid arthritis and penetration of disease-modifying drugs in Sweden. Ann Rheum Dis Apr. 2011;70(4):624-9 [Epub 2010 Dec 13].

[6] Coskun S, Özoran K, Mermerci B, Aydogdu S, Kelles T. Cardiac involvement in patients with rheumatoid arthritis. APLAR J Rheumatol 2005;8:23-31.

[7] Voskuyl AE. The heart and cardiovascular manifestations of rheumatoid arthritis. Rheumatology 2006;45:iv4-7.

[8] Solomon DH, Goodson NJ, Katz JN, et al. Patterns of cardiovascular risk in rheumatoid arthritis. Ann Rheum Dis 2006;65:1608.

[9] Nicola P, Crowson C, Maradit-Kremers H, et al. Contribution of congestive heart failure and ischemic heart disease to excess mortality in rheumatoid arthritis. Arthritis Rheum 2006;54:60-7.

[10] Corrao S, Scaglione R, Calvo L, Licata G. A meta-analysis of the effect size of rheumatoid arthritis on left ventricular mass: comment on the article by Rudominer et al. Arthritis Rheum Sep. 2009;60(9):2851-2.

[11] Corrao S, Sallì L, Arnone $\mathrm{S}$, et al. Cardiac involvement in rheumatoid arthritis: evidence of silent heart disease. Eur Heart J Feb. 1995;16(2):253-6.

[12] Yiu KH, Wang S, Mok MY, et al. Relationship between cardiac valvular and arterial calcification in patients with rheumatoid arthritis and systemic lupus erythematosus. J Rheumatol Feb. 12011.

[13] Pocock SJ, Collier TJ, Dandreo KJ, et al. Issues in the reporting of epidemiological studies: a survey of recent practice. BMJ 2004;329:883.

[14] Egger M, Schneider M, Davey Smith G. Spurious precision? Meta-analysis of observational studies. BMJ 1998;316:140.

[15] http://www.ncbi.nlm.nih.gov/pubmed/.

[16] http://mrw.interscience.wiley.com/cochrane/cochrane_clcentral_articles_fs.html.

[17] von Elm E, Altman DG, Egger M, Pocock SJ, Gøtzsche PC, Van-denbroucke JP, STROBE-Initiative. The Strengthening the Reporting of Observational Studies in Epidemiology (STROBE) statement: guidelines for reporting of observational studies. Internist (Berl) Jun. 2008;49(6):688-93 [German].

[18] Guedes C, Bianchi-Fior P, Cormier B, Barthelemy B, Rat AC, Boissier MC. Cardiac manifestations of rheumatoid arthritis: a case-control transesophageal echocardiography study in 30 patients. Arthritis Rheum Apr. 2001;45(2):129-35.
[19] Beckhauser AP, Vallin L, Burkievcz CJ, Perreto S, Silva MB, Skare TL. Valvular involvement in patients with rheumatoid arthritis. Acta Reumatol Port Jan-Mar. 2009;34(1):52-6.

[20] Wislowska M, Jaszczyk B, Kochmański M, Sypuła S, Sztechman M. Diastolic heart function in RA patients. Rheumatol Int Apr. 2008;28(6):513-9.

[21] Roldan CA, DeLong C, Qualls CR, Crawford MH. Characterization of valvular heart disease in rheumatoid arthritis by transesophageal echocardiography and clinical correlates. Am J Cardiol Aug. 1 2007;100(3):496-502.

[22] Kamiński G, Makowski K, Dziuk M, et al. Degenerative valvular and left ventricle structural changes in echocardiography in patients with rheumatoid arthritis. Pol Merkur Lekarski May 2005;18(107):496-8 [Polish].

[23] Gonzalez-Juanatey C, Testa A, Garcia-Castelo A, et al. Echocardiographic and Doppler findings in long-term treated rheumatoid arthritis patients without clinically evident cardiovascular disease. Semin Arthritis Rheum Feb. 2004;33(4): 231-8.

[24] Wisłowska M, Sypuła S, Kowalik I. Echocardiographic findings and 24-h electrocardiographic Holter monitoring in patients with nodular and non-nodular rheumatoid arthritis. Rheumatol Int 1999;18(5-6):163-9.

[25] Wisłowska M, Sypuła S, Kowalik I. Echocardiographic findings, 24-hour electrocardiographic Holter monitoring in patients with rheumatoid arthritis according to Steinbrocker's criteria, functional index, value of Waaler-Rose titre and duration of disease. Clin Rheumatol 1998;17(5):369-77.

[26] Tłustochowicz W, Cwetsch A, Cholewa M, Raczka A, Nowak J. Echocardiographic evaluation of cardiac structures in patients with rheumatoid arthritis. Pol Arch Med Wewn Apr. 1997;97(4):352-8 [Polish].

[27] Corrao S, Sallì L, Arnone S, Scaglione R, Pinto A, Licata G. Echo-Doppler left ventric ular filling abnormalities in patients with rheumatoid arthritis without clinically evident cardiovascular disease. Eur J Clin Invest 1996 Apr;26(4):293-7.

[28] Rudominer RL, Roman MJ, Devereux RB, et al. Independent association of rheumatoid arthritis with increased left ventricular mass but not with reduced ejection fraction. Arthritis Rheum Jan. 2009;60(1):22-9.

[29] Fos CS, Vasan RS, Paris H, et al. Mitral annular calcification predicts cardiovascular morbidity and mortality: the Framingham Heart Study. Circulation 2003;107: 1492-6.

[30] Barasch E, Gottdiener JS, Marino Larsen EK, Chaves PHM, Newman AB. Cardiovascular morbidity and mortality in community-dwelling elderly individuals with calcification of the fibrous skeleton of the base of the heart and atherosclerosis (The cardiovascular Health Study). Am J Cardiol 2006;97:1281-6.

[31] Coats AJ, Shewan LG. Ethics in the authorship and publishing of scientific articles Int J Cardiol 2011;153:239-40. 